\title{
Effect of Fertilizers and Foliar Application of Nutrient on Wheat (Triticum aestivum L.) Grain Yield through conduct on Farm Trails at Farmers Fields
}

\author{
Ratan Lal Solanki ${ }^{1 *}$, Priyanka Swami ${ }^{1}$, K. C. Nagar $^{2}$ and A. K. Dashora ${ }^{3}$ \\ ${ }^{1} K V K$, Chittorgarh, India \\ ${ }^{2} K V K$, Bhilwara, India \\ ${ }^{3}$ RCA, Udaipur (MPUAT, Udaipur), Rajasthan 312001, India \\ *Corresponding author
}

\begin{tabular}{l} 
Ke y w o r d s \\
Conduct OFT \\
Wheat, Fertilizer \\
application, \\
18:18:18 NPK, \\
Technology \\
dissemination, \\
Yield and \\
Economics \\
Article Info \\
\hline $\begin{array}{l}\text { Accepted: } \\
\text { 14 June } 2020 \\
\text { Available Online: } \\
\text { 10 July } 2020\end{array}$ \\
\hline
\end{tabular}

\section{A B S T R A C T}

\section{Introduction}

Wheat (Triticum aestivum L.) is the most important food grain crop cultivated Rabi season crop grown in the tropics and subtropics despite the relatively high temperature that occur during the growth cycle. Heat stress is an important constraint to wheat productivity affecting growth stages specially anthesis and grain filling. It has already been established that heat stress is significant factor in reducing the yield and quality of grains and it is a major challenge to wheat productivity in India. The current problem of wheat contributing in low yield is the use of old technology like unawareness about the efficient method and time of application of fertilizer etc. In Rajasthan, it has occupied an area of 3050235 hectare (average of 2012-13 to 2016-17) with annual production of 11280500 tonnes and average productivity is $3698 \mathrm{~kg} \mathrm{ha}^{-1}$. It is grown in all parts of Rajasthan but major area has been covered by district Sriganganagar, 
Hanumangarh, Alwar, Bharatpur, Jaipur, Bundi, Baran, Kota and Chittorgarh. The average productivity of wheat in Rajasthan ranged between $1282 \mathrm{~kg} \mathrm{ha}^{-1}$ in district Jaisalmer and $4102 \mathrm{~kg} \mathrm{ha}^{-1}$ in district Bharatpur with the state average of $3698 \mathrm{~kg}$ $\mathrm{ha}^{-1}$ (Anonymous 2017-18). The average of last five years Wheat in Chittorgarh district was 153564 hectare area with annual production of 625979 tonnes and productivity $4076 \mathrm{Kg} \mathrm{ha}^{-1}$ in year ending 2016-17, receptively. This district has greater potential of Wheat production due to favourable climatic and soil condition. Balanced and Foliar fertilization has become an established technology to enhance yield and improve quality of crop production. It also improves nutrient utilization and lower environmental pollution through reducing the amount of fertilizers added to soil especially wheat (Yaseen et al., 2011). The efficacy of foliar fertilization is higher than that of soil fertilizer application under drought and salinity situations. The reasons for this are because of the supply of the required nutrient directly to the location of demand in the leaves and its relatively quick absorption (e.g. $0.5-2.0 \mathrm{~h}$ for $\mathrm{N}$ and 10-24 $\mathrm{h}$ for $\mathrm{K}$ ), and the independence of root activity and soil water availability (Romheld and El-Fouly, 1999). Commercial fertilizers when applied during the period of low soil moisture are rapidly absorbed through foliage and enhance crop yield and quality (Smith et al., 1992). The judicious use of inorganic fertilizers can increase grain yield by 30-40 percent (Maqsood, et. al., 1999).The N, P and K are major plant food nutrients and most of soils are deficient in these nutrients (Tahir, 1980). Adequate nitrogen must be supplied to crop during growing season for achieving their full yield potential (Angus et al., 1998). Phosphorus counter balances the effect of excessive nitrogen by hastening plant maturity, improving grain quality and retarding excessive vegetative growth. It is also involved in many metabolic activities and if soil is deficient in phosphorus, the response of crop to nitrogen would be reduced (Senigagliesi et al., 1983). At early growth stages, foliar fertilization could increase $\mathrm{P}$ and $\mathrm{K}$ supplies at a time when the root system is not well developed (Mallarino et al., 2001). The foliar application of nutrients is more effective as compared to soil applied nutrients because of effective utilization by plant and minimum cost per unit area (Narang et al., 1997). Foliar application is credited with the advantage of quick and efficient utilization of nutrients, elimination of losses through leaching, fixation and regulating the uptake of nutrients by plant (Manonmani and Srimathi, 2009).

Foliar applications of macro -nutrients are more effective in term of getting maximum yield and reduce losses. In the present investigation, the crop was free from any biotic stresses. Foliar application of water soluble fertilizer is an effective method and there is a need to supplement wheat crop with proper nutrients supply in a balanced way. A liquid fertilizer is ideally suited to supply the nutrients through foliar application to help mitigate heat stress management. Application of inorganic spray will also enhance the nutrient availability and in turn increase the productivity. Nutrients play a pivotal role in increasing yield. Foliar application of major and minor nutrients like NPK shall be more effective than soil application and also avoiding the depletion of these nutrients in leaves, thereby resulting in an increased photosynthetic rate, better translocation of these nutrients from the leaves to the developing grains (Basant et al., 2020). The present study was conducted with the objectives to determine and demonstrate the effect of balanced fertilizers and foliar application of nutrients on grain yield of wheat through conduct on farm trial at farmer's fields. 


\section{Materials and Methods}

An on farm testing (OFT) was conducted at the locations in Tie, taluka of Nibaheda district of Rajasthan state during 2013-14. Wheat cv.Raj.-4037 was grown under the irrigated conditions. Soils of the experimental sites were testes and rated as per the data given in Table1. In general the soils were neutral in reaction. Organic carbon content was found low in all the locations. Available phosphorus under medium rating and available potassium status of the soil was estimated as medium to high. In all the locations the average availability of phosphorus and potassium were medium, respectively. Generally farmers were utilizing more only NP fertilizers than recommendation but not use balanced, proper method and time, which resulted into high cost of cultivation and also affected the soil health. Therefore the treatments were RDF + 18:18:18 NPK $1 \%$ foliar spray application compared in these trials in order to check the performance of exiting production farmers practices with the RDF- $120 \mathrm{Kg} \mathrm{N}+40 \mathrm{~kg}$ $\mathrm{P}_{2} \mathrm{O}_{5}+30 \mathrm{Kg} \mathrm{K}_{2} \mathrm{O} \mathrm{ha}^{-1}+18: 18: 18$ NPK $1 \%$ foliar spray (Foliar spray were applied at flowering stage of wheat crop) application technique. The details of the treatment are given in Table 2.

\section{Liquid mix 18:18:18 (NPK)}

18-18-18 mix is a balanced liquid N-P-K fertilizer, suitable for all crops, during all stages of plant growth. 18-18-18 mix liquid fertilizer provides an additional source of nitrogen, phosphorous and potassium during the growing season. 18-18-18 mix NPK liquid fertilizer is in the form readily absorbed by plant tissue. 18-18-18 mix NPK is manufactured by utilizing quality raw materials to provide a very ergonomically efficient source of N-P-K. The quality of the raw materials used to formulate $18-18-18$ mix
NPK maximized plant nutrient solubility. The average yield of OFT treatments and farmer practice has been taken in the year for interpretation of the results. The economicparameters (gross return, net return and B: C ratio) were worked out on the basis of prevailing market prices of inputs and minimum support prices of outputs.

\section{Results and Discussion}

The results presented in Table 3 revealed that Wheat yields were influenced due to different treatments. The increasing trend in yield was observed under different treatment. Treatment $\mathrm{T}_{3}-\mathrm{RDF}-120 \mathrm{Kg} \mathrm{N}_{2}+40 \mathrm{~kg} \mathrm{P}_{2} \mathrm{O}_{5}+30 \mathrm{Kg}$ $\mathrm{K}_{2} \mathrm{O}$ ha $^{-1}$ (Whole $\mathrm{P}+1 / 3 \mathrm{~N}$ as basal \& remaining $\mathrm{N}$ as two split at $25 \& 45 \mathrm{DAS}+$ 18:18:18 NPK 1\% foliar spray (Foliar spray were applied at flowering stage of wheat crop) recorded highest yield of Wheat (62.60 $\mathrm{q} \mathrm{ha}^{-1}$ ) as compared to treatment $\mathrm{T}_{2}-120 \mathrm{Kg} \mathrm{N} \mathrm{N}_{2}$ $+40 \mathrm{kgP}_{2} \mathrm{O}_{5}+30 \mathrm{Kg} \mathrm{K}_{2} \mathrm{O} \mathrm{ha}^{-1}$ (RDF) Whole $\mathrm{P}+1 / 2 \mathrm{~N}$ as basal \& remaining $1 / 2 \mathrm{~N}$ at 25 DAS $\left(61.30 \mathrm{q} \mathrm{ha}^{-1}\right)$ than $\mathrm{T}_{1}$ - Farmers practice $\left(100 \mathrm{~kg} \mathrm{~N}+40 \mathrm{~kg} \mathrm{P}_{2} \mathrm{O}_{5} \mathrm{ha}^{-1}\right)$ were recorded $\left(57.10 \mathrm{q} \mathrm{ha}^{-1}\right)$ respectively-. It was observed that farmers practice $\left(T_{1}\right)$ recorded lower yield than that of recorded under exiting recommended practices (RDF). Similar findings of our studies are in line with by Kirar et al., (2006) and Muhammad et al., (2006), reported that by the use of foliar application all respects of wheat crop found very significant.

The balanced fertilizers application of treatment $\mathrm{T}_{3}-120 \mathrm{Kg} \mathrm{N} \mathrm{N}_{2}+40 \mathrm{~kg} \mathrm{P}_{2} \mathrm{O}_{5}+30$ $\mathrm{Kg} \mathrm{K}_{2} \mathrm{O} \mathrm{ha}^{-1}+18: 18: 18$ NPK $1 \%$ foliar spray at flowering stage recorded higher yield to the tune of 2.12 and 09.63 per cent, over treatment $\mathrm{T}_{2}-\left(120 \mathrm{Kg} \mathrm{N}+40 \mathrm{~kg} \mathrm{P}_{2} \mathrm{O}_{5}+30\right.$ $\mathrm{Kg} \mathrm{K}_{2} \mathrm{O} \mathrm{ha}^{-1}$ ) and $\mathrm{T}_{1}$ (Farmers practice -100 $\mathrm{kg} \mathrm{N}+40 \mathrm{~kg} \mathrm{P}_{2} \mathrm{O}_{5} \mathrm{ha}^{-1}$ ) respectively. With regards to economics, again $\mathrm{T}_{3}-120 \mathrm{Kg} \mathrm{N} \mathrm{N}_{2}+$ $40 \mathrm{~kg} \mathrm{P}_{2} \mathrm{O}_{5}+30 \mathrm{Kg} \mathrm{K}_{2} \mathrm{O} \mathrm{ha}^{-1}+18: 18: 18 \mathrm{NPK}$ 
$1 \%$ foliar spray at flowering stage treatment recorded maximum gross monetary return (Rs. 90720 ha $^{-1}$ ), net return (Rs. 63970 ha $^{-1}$ ) and $\mathrm{B}: \mathrm{C}$ ratio (2.39) as compared to treatment $T_{2}$ and $T_{1}$.

Table.1 Soil nutrient of selected location (Average) for conduct OFT

\begin{tabular}{|l|l|l|l|}
\hline S.No. & Parameters & Result & Category \\
\hline $\mathbf{1}$ & pH & 7.94 & Normal \\
\hline $\mathbf{2}$ & Electrical Conductivity $\left(\mathrm{dSm}^{-}{ }^{1}\right)$ & 0.33 & Normal \\
\hline $\mathbf{3}$ & ${\text { Available P }\left(\mathrm{Kg} \mathrm{ha-}^{1}\right)}^{1}$ & 28.0 & Medium \\
\hline $\mathbf{4}$ & ${\text { Available K }\left(\mathrm{kg} \mathrm{ha}^{-}\right)}^{-}$ & 316.0 & Medium \\
\hline $\mathbf{5}$ & Organic carbon $\left.(\%)^{\circ}\right)$ & 0.48 & Low \\
\hline
\end{tabular}

Table.2 Treatment details of conduct on farm trail at farmers fields

\begin{tabular}{|c|c|c|}
\hline S.No. & Treatments & Treatment details \\
\hline 1 & $\mathrm{~T}_{1}$-Farmer's Practices & Farmers practice $\left(100 \mathrm{~kg} \mathrm{~N}+40 \mathrm{~kg} \mathrm{P}_{2} \mathrm{O}_{5} \mathrm{ha}^{-1}\right.$.) \\
\hline 2 & $\begin{array}{l}\mathrm{T}_{2} \text {-Recommended dose of } \\
\text { fertilizers }(\mathrm{RDF})\end{array}$ & $\begin{array}{l}120 \mathrm{Kg} \mathrm{N}+40 \mathrm{~kg} \mathrm{P}_{2} \mathrm{O}_{5}+30 \mathrm{Kg} \mathrm{K}_{2} \mathrm{O} \mathrm{ha}^{-1} \\
(\mathrm{RDF}) \text { Whole } \mathrm{P}+1 / 2 \mathrm{~N} \text { as basal \& remaining } 1 / 2 \\
\mathrm{~N} \text { at } 25 \text { DAS }\end{array}$ \\
\hline 3 & $\begin{array}{l}\mathrm{T}_{3} \text { - Recommended dose of } \\
\text { fertilizers + Refinement treatment } \\
\text { use foliar spray } 18: 18: 18 \mathrm{NPK} \\
1 \%\end{array}$ & $\begin{array}{l}120 \mathrm{Kg} \mathrm{N}_{2}+40 \mathrm{~kg} \mathrm{P}_{2} \mathrm{O}_{5}+30 \mathrm{Kg} \mathrm{K}_{2} \mathrm{O}^{-1} \\
(\mathrm{Whole} \mathrm{P}+1 / 3 \mathrm{~N} \text { as basal \& remaining } \mathrm{N} \text { as two } \\
\text { split at } 25 \& 45 \mathrm{DAS})+18: 18: 18 \mathrm{NPK} 1 \% \\
\text { spray use at flowering stage }\end{array}$ \\
\hline
\end{tabular}

Table.3 Yield and economics as influence by different treatments of OFT

\begin{tabular}{|c|c|c|c|c|c|c|}
\hline S.No. & Treatments & $\begin{array}{l}\text { Wheat } \\
\text { Yield } \\
\text { q ha }\end{array}$ & $\begin{array}{l}\text { Cost of } \\
\text { Cultivation } \\
\text { (Rs.) ha }{ }^{-1}\end{array}$ & $\begin{array}{l}\text { Gross } \\
\text { Return } \\
(\mathbf{R s}) \text { ha }^{-1}\end{array}$ & $\begin{array}{l}\text { Net } \\
\text { Returns } \\
\text { (Rs.) } \\
\text { ha }^{-1}\end{array}$ & $\begin{array}{l}\text { B:C } \\
\text { Ratio }\end{array}$ \\
\hline 1 & $\begin{array}{l}\mathrm{T}_{1} \text { - Farmers practice }(100 \mathrm{~kg} \mathrm{~N}+ \\
\left.40 \mathrm{~kg} \mathrm{P}_{2} \mathrm{O}_{5} \mathrm{ha}^{-1} .\right)\end{array}$ & 57.10 & 25190 & 82825 & 57695 & 2.29 \\
\hline 2 & $\begin{array}{l}\mathrm{T}_{2}-120 \mathrm{Kg} \mathrm{N}_{2}+40 \mathrm{~kg} \mathrm{P}_{2} \mathrm{O}_{5}+30 \\
\mathrm{Kg} \mathrm{K}_{2} \mathrm{O} \mathrm{ha}^{-1}(\mathrm{RDF})\end{array}$ & 61.30 & 26400 & 88925 & 62585 & 2.37 \\
\hline 3 & $\begin{array}{l}\mathrm{T}_{3}-120 \mathrm{Kg} \mathrm{N}_{2}+40 \mathrm{~kg} \mathrm{P}_{2} \mathrm{O}_{5}+30 \\
\mathrm{Kg} \mathrm{K}_{2} \mathrm{O} \mathrm{ha}^{-1}+18: 18: 18 \mathrm{NPK} 1 \% \\
\text { foliar spray at flowering stage }\end{array}$ & 62.60 & 26750 & 90720 & 63970 & 2.39 \\
\hline
\end{tabular}

In conclusion it may be concluded that the yield and returns in Wheat crop increased substantially with the improved production technologies. However, the yield level under 
OFT refinement treatment was better than the farmer practice and performance of these varieties could be further improved by adopting recommended production technologies. So, there is need to disseminate the improved technologies among the farmers with effective extension methods like conduct on farm trail demonstrations. The farmers should be encouraged to adopt the recommended balanced fertilizers-techniques for getting maximum returns in specific locations. Thus, it was clearly showed that the OFT of Wheat with full RDF package + applied 18:18:18 NPK 1\% foliar spray was better to farmer's practices. The results indicated that the OFT treatment has given a good impact on the farming community of the district Chittorgarh (Rajasthan) as they were motivated by the new agricultural technology applied in the OFT plots. Similar findings were reported by Kirar et al., (2006). Foliar spray of $1 \%$ soluble NPK, $1 \%$ DAP, $0.5 \%$ $\mathrm{KCl}$ and $1 \%$ urea at tillering and flowering stages enhance the grain yield of wheat and found economical also. Therefore, the use of these fertilizers may be promoted at farmer's fields for augmenting the Wheat production in Rajasthan. The maximum gross monetary return of Rs $90720 \mathrm{ha}^{-1}$ and benefit: cost ratio of 2.39 was obtained. Therefore it is clear from the full recommendation dose fertilizers and applied 18:18:18 NPK 1\% foliar spray at flowering stage performed better, enhance the wheat productivity as compared to other treatment.

\section{Acknowledgement}

I am sincerely thankful to all the farmers on whose field OFT were conducted. The financial assistance provided by Indian Council for Agricultural Research, New Delhi and Director, ICAR -Agricultural Application Research Institute (ATRI), Zone- II,, Jodhpur (Rajasthan) India. The opinions expressed in this paper are the author's own and do not necessarily reflect the views of the donor or the authors' institution.

\section{References}

Anonymous, 2017-18. Rajasthan Agricultural Statistics -At a glance, Department of Agriculture, Government of Rajasthan, $74 \mathrm{p}$.

Angus, J.F., Herwaarden, A.F., Fischer, R.A., Howe, G.N. and Heenan, D.P. 1998. The source of mineral nitrogen for cereals in south-eastern Australia. Australian Journal of Agricultural Research: 511-522.

Basant K.M., R.P. Singh, Dubey M., Waskle, U., and Birla, B.2020. Effect of Foliar Application of Nutrients on Growth and Yield Attributing Characters of Black Gram. Int.J.Curr.Microbiol.App.Sci 9(2): 419-428

Muhammad, Arif., Muhammad, A., Chohan, S. A., Rozina,G. and Sajjad, K., 2006, Response of wheat to foliar application of nutrients. J. Agril. Sci., 1: 30-34.

Maqsood M., Akbar, M., Yousaf, N., Mehmood, M.T. and Ahmad, S. 1999. Effect of different rate of $\mathrm{N}, \mathrm{P}$ and $\mathrm{K}$ combinations on yield and components of yield of wheat. International Journal of Agriculture and Biology 1(4): 359361 .

Mallarino A.P., Haq, M.U., Wittry, D. and Bermudez, M. 2001. Variation in soybean response to early season foliar fertilization among and within fields. Agronomy Journal 93: 1120-1226.

Manonmani, V. and Srimathi, P. (2009). Influence of mother crop nutrition on seed and quality of balckgram. Madras Agriculture Journal. 96 (16): 125128.

Narang R.S., Mahal, S.S., Bedi, S., Gosal, K.S. and Bedi, S. 1997. Response of wheat to potassium fertilization under maximum yield research strategies. Environmental Ecology 15(2): 474477. 
Njuguna M.N., Macharia, M., Akuja, T.E., Waweru, J.K. and Kamwaga, J.N. 2011. Effect of foliar fertilization on wheat Triticul aestivum in marginal areas of Eastern Province, Kenya. Journal of Animal \& Plant Science 9(2): 11791182.

Romheld V. and El-Fouly, M.M. 1999. Foliar nutrient application: Challenge and limits in crop production. Proc. of 2nd International workshop on foliar fertilization April 4-10, Bankok, Thailand, pp 1-34.

Senigagliesi C.A., Garcia, R., Meria, S., Galetto, M.L.R., dr Frusos and Teves, R. 1983. Fertilizer application to wheat in the north of province of Bunenos
Aires and South of Santa Fe. Agropecuaria Pergammo 191: 28 Argentina (Field Crop Abstract 37: 5117; 1984).

Smith C.J., Frennery, J.R., Sharlock, R.R. and Gallbally, I.E. 1992. The fate of urea nitrogen applied in foliar spray to wheat at heading. Nutrient Cycling in Agroecosystem 28(2): 129-138.

Tahir, M. 1980. Wheat production manual, Pakistan Agriculture Research Council, Islamabad, Pakistan, $59 \mathrm{p}$.

Yaseen M., Ahmed, W., Arshad, M. and Ali, Q. 2011. Response of wheat to foliar feeding of micronutrients. IJAVMS 5(2): 209-220.

\section{How to cite this article:}

Ratan Lal Solanki, Priyanka Swami, K. C. Nagar and Dashora, A. K. 2020. Effect of Fertilizers and Foliar Application of Nutrient on Wheat (Triticum aestivum L.) Grain Yield through conduct on Farm Trails at Farmers Fields. Int.J.Curr.Microbiol.App.Sci. 9(07): 1551-1556. doi: https://doi.org/10.20546/ijcmas.2020.907.179 